\title{
Sensitivity of Colletotrichum gloeosporioides Isolates from Diseased Avocado Fruits to Selected Fungicides in Kenya
}

\author{
Stanley Kirugo Kimaru $\mathbb{D}^{1},{ }^{1}$ E. Monda, ${ }^{2}$ R. C. Cheruiyot, ${ }^{1}$ J. Mbaka, ${ }^{3}$ and A. Alakonya ${ }^{4}$ \\ ${ }^{1}$ Department of Plant Sciences, Kenyatta University, P.O. Box 43844, Nairobi, Kenya \\ ${ }^{2}$ Department of Microbiology, Kenyatta University, P.O. Box 43844, Nairobi, Kenya \\ ${ }^{3}$ Kenya Agricultural and Livestock Research Organization, P.O. Box 220, Thika, Kenya \\ ${ }^{4}$ Jomo Kenyatta University of Agriculture and Technology, P.O. Box 62000-00200 Nairobi, Kenya
}

Correspondence should be addressed to Stanley Kirugo Kimaru; skimarul@gmail.com

Received 1 November 2017; Revised 24 January 2018; Accepted 11 February 2018; Published 11 March 2018

Academic Editor: Othmane Merah

Copyright (C) 2018 Stanley Kirugo Kimaru et al. This is an open access article distributed under the Creative Commons Attribution License, which permits unrestricted use, distribution, and reproduction in any medium, provided the original work is properly cited.

Colletotrichum gloeosporioides is a serious postharvest pathogen of avocado fruits worldwide. Kenya lacks any registered fungicides for the management of the disease. Nevertheless, farmers commonly use commercially available fungicides such as Bayleton 25WP (Triadimefon $250 \mathrm{~g} / \mathrm{Kg}$ ), Milraz 76WP (Propineb 70\% and Cymoxanil 6\%), and Copper oxychloride 500WP for disease management. The efficacy of these fungicides against C. gloeosporioides is not known. The purpose of this study was therefore to test the inhibitory effect of these fungicides against 46 C. gloeosporioides isolates from avocado fruits collected from varieties grown at different agroecological zones in Murang'a County, a popular avocado-growing region in Kenya. Mycelial growth rate and sporulation for each isolate were measured in vitro on PDA plates amended with different concentrations of the fungicides. Plates were arranged in a completely randomized design with three replications per treatment. All fungicides were effective in vitro but there were significant differences in sensitivity among isolates. Bayleton had the highest mycelial inhibition followed by Milraz, while copper oxychloride had the lowest mycelial inhibition rates, ranging from $81 \%$ to $88 \%$. However, copper oxychloride was more effective in inhibiting sporulation. The inhibitory effect of each fungicide was concentration-dependent, where twice the recommended concentration had the highest inhibitory effect, followed by the recommended concentration. Our results show that the fungicides used by farmers against $C$. gloeosporioides, the causal agent for anthracnose, are effective. We, however, recommend further field tests in different avocado-growing areas so as to validate their efficacy against various isolates and under different environments.

\section{Introduction}

Anthracnose caused by Colletotrichum gloeosporioides (Penz.) Penz \& Sacc. has been reported on a wide variety of crops, such as avocado, almond, coffee, guava, apple, dragon fruit, cassava, mango, sorghum, and strawberry [1-3]. Colletotrichum gloeosporioides is a significant economic constraint to avocado production worldwide [4]. Anthracnose disease can occur on avocado fruits from setting until harvest. The disease results in fruit abortion and may also manifest as black spots on fruits which lower fruit quality $[5,6]$.

The disease inoculum is mainly conidia from diseased dead wood, leaves entangled in the tree canopy, branch terminals, mummified fruits, and flower bracts [7]. The conidia are disseminated through rainfall, irrigation, and heavy dew [8].

Disease management includes cultural, chemical, and biological control, along with the use of resistant cultivars [9-12]. Cultural control of anthracnose requires good orchard sanitation procedures. Furthermore, adequate postharvest handling practices must be applied to prevent cuts and bruises to fruit surfaces. Fruits showing symptoms of postharvest disease should not be packed into cartons containing healthy fruits. Biocontrol agents such as Streptomyces sp. A1022 [13], use of food preservatives such as carbonates, bicarbonates, and potassium sorbate [12], heat treatments [14], UV irradiation [15], microwaves [16], chitosan [17], and 
TABLE 1: Fungicides concentrations used to determine sensitivity of Colletotrichum gloeosporioides isolates from diseased avocado fruits.

\begin{tabular}{|c|c|c|c|}
\hline Trade name & Active ingredient (AI) & Concentration $(\mathrm{g} / \mathrm{l})$ & Concentration $(\mathrm{g} / \mathrm{l})$ for inhibition test \\
\hline \multirow{3}{*}{ Bayleton 25WP } & \multirow{3}{*}{ Triadimefon } & \multirow{3}{*}{0.25} & 0.500 \\
\hline & & & 0.250 \\
\hline & & & 0.125 \\
\hline \multirow{3}{*}{ Milraz 76WP } & \multirow{3}{*}{ Propineb $70 \%$ and Cymoxanil 6\% } & \multirow{3}{*}{0.50} & 1.00 \\
\hline & & & 0.50 \\
\hline & & & 0.25 \\
\hline \multirow{3}{*}{ Green Cop 500WP } & \multirow{3}{*}{ Copper oxychloride } & \multirow{3}{*}{1.75} & 3.50 \\
\hline & & & 1.75 \\
\hline & & & 0.88 \\
\hline
\end{tabular}

natural products such as essential oils $[18,19]$ have been used to control the postharvest disease.

Chemical control during fruit development is the main strategy to reduce the incidence of postharvest diseased fruits [20]. Application of fungicides such as Benomyl, Mancozeb, Metiram, Propineb, Thiabendazole, and Prochloraz has been used for disease management in South Africa, New Zealand, and Australia [21, 22]. Prochloraz, a nonsystemic fungicide, has been used in the packing line to control postharvest disease development. It affects the mycelial growth of the pathogens and acts as a sterol inhibitor impeding the synthesis of a fatty acid ergosterol, an important component in fungal cell wall development $[9,10]$.

In Kenya, management of anthracnose in avocado has been a challenge due to lack of registered fungicides. Fungicides registered for the management of fungal pathogens in other crops such as Bayleton 25WP (Triadimefon $250 \mathrm{~g} / \mathrm{Kg}$ ), Milraz 76WP (Propineb 70\% and Cymoxanil 6\%), and Green Cop 500WP (copper oxychloride $500 \mathrm{~g} / \mathrm{Kg}$ ) have been used for anthracnose management in avocado.

Inhibitory effect of Bayleton $25 \mathrm{WP}$ (Triadimefon $250 \mathrm{~g} / \mathrm{Kg}$ ), Milraz $76 \mathrm{WP}$ (Propineb 70\% and Cymoxanil 6\%), and Green Cop 500WP (copper oxychloride $500 \mathrm{~g} / \mathrm{Kg}$ ) used by farmers to control anthracnose in avocado in Kenya has not been determined. The aim of this study was to provide information on the efficacy of the fungicides against $C$. gloeosporioides isolates in Kenya with the aim of providing preliminary technical information required for further testing and possible registration of the effective fungicides against avocado anthracnose in Kenya.

\section{Materials and Methods}

2.1. Source of Isolates. Samples of infected fruits were randomly collected from avocado orchards in Murang'a County and taken to the laboratory. The fruits were washed using tap water and blotted to remove excess water. The fruits were surface-sterilized using $0.5 \%$ sodium hypochlorite for 30 seconds. Small sections from the edge of necrotic area were cut aseptically and plated on potato dextrose agar (PDA). Hyphal tips of the mycelia were subcultured to obtain pure cultures. Colletotrichum gloeosporioides was morphologically identified based on cultural and microscopic characteristics. Single-spore cultures were preserved on PDA slant universal bottle and stored at $4^{\circ} \mathrm{C}$. A total of 46 isolates were used in this experiment.

2.2. Preparation of Fungicides Inhibition Treatments. In a previous survey, Bayleton $25 \mathrm{WP}$ (Triadimefon $250 \mathrm{~g} / \mathrm{Kg}$ ), Milraz 76 WP (Propineb 70\% and Cymoxanil 6\%), and Green Cop 500WP (copper oxychloride $500 \mathrm{~g} / \mathrm{Kg}$ ) were identified as the fungicides used by farmers to control anthracnose. The concentrations used were determined based on the manufacturer's recommended doses on the fungicide label. Three concentrations of each fungicide were formulated for use as follows; twice the recommended rate, the recommended rate, and half the recommended rate (Table 1). Fungicide suspensions were prepared by dissolving specific quantities of each fungicide in warm PDA medium after autoclaving. About $15 \mathrm{ml}$ of fungicide amended PDA medium was poured into sterile $9 \mathrm{~cm}$ diameter Petri dishes. Each fungicide concentration was replicated three times. Petri dishes with nonamended PDA media served as controls.

Disks of PDA, $5 \mathrm{~mm}$ in diameter, with actively growing mycelium of 7-day-old cultures, were cut out with sterile cork borer and placed in the centre of each plate. The amended and control Petri dishes inoculated with mycelia plugs were arranged in a completely randomized design in a sterile hood/chamber at room temperatures of $22-24^{\circ} \mathrm{C}$ in the Mycology Laboratory, KALRO, Kandara. The fungi were allowed to grow until mycelia growth covered the entire surface of the control plates.

2.3. Evaluation of Fungicides on Mycelia Growth Rate and Sporulation. After every two days, radial mycelial growth measurements were taken on each plate and recorded. Final measurements were taken after ten days when fungal growth in the control plates fully covered the plates and these measurements were used for data analysis. Inhibition of radial growth due to various fungicidal treatments was computed based on colony diameter on control plate using the following formula as described by [23]:

$$
\% \text { inhibition }=\frac{x-y}{x} \times 100,
$$

where $x$ is growth in control plate and $y$ is growth in fungicide-treated plate. 
TABLE 2: Effect of selected fungicides on mycelial growth of Colletotrichum gloeosporioides isolates.

\begin{tabular}{|c|c|c|}
\hline Fungicide & Concentration (g/l) & Mean inhibition (\%) \\
\hline \multirow{5}{*}{ Milraz } & 0.25 & $82.1^{* c}$ \\
\hline & 0.50 (recommended) & $84.1^{\mathrm{b}}$ \\
\hline & 1.00 & $85.9^{\mathrm{a}}$ \\
\hline & LSD & 1.5184 \\
\hline & $P$ value & $<0.001$ \\
\hline \multirow{5}{*}{ Copper oxychloride } & 0.88 & $80.9^{c}$ \\
\hline & 1.75 (recommended) & $83.3^{\mathrm{b}}$ \\
\hline & 3.50 & $85.1^{\mathrm{a}}$ \\
\hline & LSD & 1.035 \\
\hline & $P$ value & $<0.001$ \\
\hline \multirow{5}{*}{ Bayleton } & 0.13 & $84.5^{\mathrm{c}}$ \\
\hline & 0.25 (recommended) & $86.2^{\mathrm{b}}$ \\
\hline & 0.50 & $87.6^{\mathrm{a}}$ \\
\hline & LSD & 0.6423 \\
\hline & $P$ value & $<0.001$ \\
\hline
\end{tabular}

${ }^{*}$ Data represent means of three replications. Means followed by same letter are not significantly different at $P \geq 0.05$ according to Fisher's protected LSD test.

Further, the plates were flooded with $15 \mathrm{ml}$ distilled water to bring the spores into suspension. Sporulation capacity was determined by counting the number of spores using a hemocytometer. Sporulation was expressed as the total number of spores as determined from $1 \mathrm{ml}$ subsample.

2.4. Data Analysis. Analysis of variance (ANOVA) was used to compare fungicides inhibition percentages (radial mycelial growth and sporulation) using statistical Genstart version 6 software at $95 \%$ confidence level. Treatments were separated using Fisher's protected Least Significant Difference (LSD) test.

\section{Results and Discussion}

The mycelial growth of C. gloeosporioides isolates was inhibited significantly by the three fungicides' treatments with growth rates reduced by more than $80 \%$ (Table 2 ). Sanders et al. [24] observed similar results, where most of the $C$. gloeosporioides isolates obtained from diseased avocado fruits were highly sensitive to Prochloraz and Thiabendazole, with no growth being observed. The mycelial growth inhibition from the fungicide treatment significantly increased with an increase in the fungicide concentration (Table 2); however, none of the concentrations evaluated completely inhibited mycelial growth. Similar observations were made by Sanders et al., [24] when C. gloeosporioides isolates were subjected to various concentrations of Benomyl fungicide in vitro.

Among the fungicides, Bayleton had the highest mean inhibition percentages, with copper oxychloride showing the lowest inhibition percentages (Table 2). These fungicides probably acted as a sterol inhibitor impeding the ergosterol (fatty acid) synthesis, which is an important component of the fungal cell wall [12].

Inhibition of mycelial growth could further be explained by the multisite activity of the fungicide such as Milraz
(Propineb and Cymoxanil), which inhibits synthesis of nucleic acids, amino acids, and other cellular processes [25].

Although farmers have been using these fungicides on avocado, they are not registered as preharvest chemical treatments for anthracnose on avocados in Kenya. Similarly, farmers have been using Benomyl for the management of anthracnose of avocado in South Africa although it is registered for the control of Cercospora spot of avocado [24]. Use of fungicides whose efficacy has not been tested might lead to incorrect application rate, which could favour the development of resistant strains of the causal agent [5].

The mean number of spores recorded from C. gloeosporioides isolates treated with different concentrations of fungicides differed significantly (Table 3). Isolates treated with different concentrations of Bayleton produced a higher number of spores as compared to Milraz and copper oxychloride treatments (Table 4). As the concentration of the fungicide was increased, spore production was significantly reduced but was not eliminated.

\section{Conclusion}

All the isolates were sensitive to Bayleton, Milraz, and copper oxychloride in vitro. Bayleton is the most effective fungicide in inhibiting mycelial growth and sporulation of $C$. gloeosporioides in vitro.

\section{Recommendation}

Further field tests should be done in different avocadogrowing areas so as to validate these fungicides' efficacy against various isolates and under different environments.

\section{Conflicts of Interest}

The authors have no conflicts of interest to declare. 
TABLE 3: Mean number of spores/ml from 46 Colletotrichum gloeosporioides isolates treated with three fungicides $\left(\times 10^{6}\right) / \mathrm{ml}$.

\begin{tabular}{|c|c|c|c|c|c|}
\hline \multicolumn{2}{|c|}{ Copper oxychloride } & \multicolumn{2}{|c|}{ Milraz } & \multicolumn{2}{|c|}{ Bayleton } \\
\hline Isolate & Mean & Isolate & Mean & Isolate & Mean \\
\hline ko 2a & $2.86^{* a}$ & G16b & $3.25^{\mathrm{a}}$ & ko20b & $4.25^{\mathrm{a}}$ \\
\hline $\mathrm{k} 19 \mathrm{~b}$ & $2.63^{\mathrm{ab}}$ & kal4b & $2.50^{\mathrm{b}}$ & ka30b & $3.75^{\mathrm{ab}}$ \\
\hline kalc & $2.63^{\mathrm{ab}}$ & ka30b & $2.50^{\mathrm{b}}$ & ko $12 \mathrm{c}$ & $3.63^{\mathrm{a}-\mathrm{c}}$ \\
\hline ko24b & $2.63^{\mathrm{ab}}$ & ko20c & $2.50^{\mathrm{b}}$ & $\mathrm{k} 20 \mathrm{c}$ & $3.50^{\mathrm{a}-\mathrm{d}}$ \\
\hline ko31c & $2.63^{\mathrm{ab}}$ & ko30a & $2.50^{\mathrm{b}}$ & ko14a & $3.38^{\mathrm{b}-\mathrm{e}}$ \\
\hline G16b & $2.50^{a-c}$ & ko20b & $2.38^{\mathrm{bc}}$ & ko29a & $3.25^{\mathrm{b}-\mathrm{f}}$ \\
\hline $\mathrm{k} 24 \mathrm{c}$ & $2.50^{a-c}$ & $\mathrm{k} 15 \mathrm{a}$ & $2.25^{\mathrm{b}-\mathrm{d}}$ & $\mathrm{k} 10 \mathrm{~b}$ & $3.13^{\mathrm{b}-\mathrm{g}}$ \\
\hline ka12a & $2.50^{\mathrm{a}-\mathrm{c}}$ & G22b & $2.13^{\mathrm{b}-\mathrm{e}}$ & ko24b & $3.13^{b-g}$ \\
\hline ka30b & $2.50^{\mathrm{a}-\mathrm{c}}$ & G8a & $2.13^{\mathrm{b}-\mathrm{e}}$ & $\mathrm{k} 20 \mathrm{a}$ & $3.00^{\mathrm{b}-\mathrm{h}}$ \\
\hline ko15c & $2.38^{\mathrm{a}-\mathrm{d}}$ & $\mathrm{ka} 22 \mathrm{~b}$ & $2.13^{\mathrm{b}-\mathrm{e}}$ & ka25 a & $3.00^{\mathrm{b}-\mathrm{h}}$ \\
\hline G20b & $2.25^{\mathrm{a}-\mathrm{e}}$ & ko31c & $2.13^{\mathrm{b}-\mathrm{e}}$ & ko $2 \mathrm{a}$ & $3.00^{\mathrm{b}-\mathrm{h}}$ \\
\hline $\mathrm{k} 10 \mathrm{c}$ & $2.25^{\mathrm{a}-\mathrm{e}}$ & G9a & $2.00^{\mathrm{b}-\mathrm{f}}$ & kol3b & $3.00^{\mathrm{b}-\mathrm{h}}$ \\
\hline ka24a & $2.25^{\mathrm{a}-\mathrm{e}}$ & $\mathrm{k} 20 \mathrm{a}$ & $2^{b-f}$ & ko20c & $3.00^{\mathrm{b}-\mathrm{h}}$ \\
\hline K20c & $2.13^{\mathrm{b}-\mathrm{f}}$ & ko 2a & $2.00^{\mathrm{b}-\mathrm{f}}$ & $\mathrm{k} 15 \mathrm{~b}$ & $2.88^{\mathrm{c}-\mathrm{i}}$ \\
\hline $\mathrm{ka} 26 \mathrm{c}$ & $2.13^{\mathrm{b}-\mathrm{f}}$ & ko14a & $2.00^{\mathrm{b}-\mathrm{f}}$ & k19b & $2.88^{\mathrm{c}-\mathrm{i}}$ \\
\hline kollb & $2.13^{\mathrm{b}-\mathrm{f}}$ & G19c & $1.88^{\mathrm{c}-\mathrm{g}}$ & kal4b & $2.88^{\mathrm{c}-\mathrm{i}}$ \\
\hline kol7c & $2.13^{\mathrm{b}-\mathrm{f}}$ & G20b & $1.88^{\mathrm{c}-\mathrm{g}}$ & Ka 24a & $2.88^{\mathrm{c}-\mathrm{i}}$ \\
\hline G19c & $2.00^{\mathrm{b}-\mathrm{g}}$ & $\mathrm{k} 10 \mathrm{~b}$ & $1.88^{\mathrm{c}-\mathrm{g}}$ & kol3a & $2.88^{\mathrm{c}-\mathrm{i}}$ \\
\hline G8a & $2.00^{\mathrm{b}-\mathrm{g}}$ & $\mathrm{k} 10 \mathrm{c}$ & $1.88^{\mathrm{c}-\mathrm{g}}$ & ko16a & $2.88^{\mathrm{c}-\mathrm{i}}$ \\
\hline G9a & $2.00^{\mathrm{b}-\mathrm{g}}$ & $\mathrm{K} 20 \mathrm{c}$ & $1.88^{\mathrm{c}-\mathrm{g}}$ & ko7c & $2.88^{\mathrm{c}-\mathrm{i}}$ \\
\hline kal6 c & $2.00^{\mathrm{b}-\mathrm{g}}$ & ka12a & $1.88^{\mathrm{c}-\mathrm{g}}$ & $\mathrm{k} 15 \mathrm{a}$ & $2.75^{\mathrm{d}-\mathrm{j}}$ \\
\hline ko13b & $2.00^{\mathrm{b}-\mathrm{g}}$ & kollb & $1.88^{\mathrm{c}-\mathrm{g}}$ & kol7c & $2.75^{\mathrm{d}-\mathrm{j}}$ \\
\hline $\mathrm{k} 15 \mathrm{~b}$ & $1.88^{\mathrm{c}-\mathrm{h}}$ & ko29b & $1.88^{\mathrm{c}-\mathrm{g}}$ & G8a & $2.63^{\mathrm{e}-\mathrm{k}}$ \\
\hline ko29a & $1.88^{\mathrm{c}-\mathrm{h}}$ & G12a & $1.75^{\mathrm{d}-\mathrm{h}}$ & ka16 c & $2.63^{e-k}$ \\
\hline ko7c & $1.88^{\mathrm{c}-\mathrm{h}}$ & Ka 31b & $1.75^{\mathrm{d}-\mathrm{h}}$ & $\mathrm{ka} 22 \mathrm{~b}$ & $2.63^{\mathrm{e}-\mathrm{k}}$ \\
\hline G12a & $1.75^{\mathrm{d}-\mathrm{i}}$ & ko16a & $1.75^{\mathrm{d}-\mathrm{h}}$ & ko20a & $2.63^{\mathrm{e}-\mathrm{k}}$ \\
\hline $\mathrm{k} 20 \mathrm{a}$ & $1.75^{\mathrm{d}-\mathrm{i}}$ & kol7c & $1.75^{\mathrm{d}-\mathrm{h}}$ & ko30a & $2.50^{\mathrm{f}-1}$ \\
\hline ka9a & $1.75^{\mathrm{d}-\mathrm{i}}$ & ko20a & $1.75^{\mathrm{d}-\mathrm{h}}$ & G12a & $2.38^{\mathrm{g}-\mathrm{m}}$ \\
\hline kol3c & $1.75^{\mathrm{d}-\mathrm{i}}$ & $\mathrm{k} 19 \mathrm{~b}$ & $1.63^{\mathrm{e}-\mathrm{i}}$ & G16b & $2.38^{\mathrm{g}-\mathrm{m}}$ \\
\hline ko20c & $1.75^{\mathrm{d}-\mathrm{i}}$ & kol3b & $1.63^{\mathrm{e}-\mathrm{i}}$ & kalc & $2.38^{\mathrm{g}-\mathrm{m}}$ \\
\hline $\mathrm{k} 10 \mathrm{~b}$ & $1.63^{e-j}$ & kol3c & $1.63^{\mathrm{e}-\mathrm{i}}$ & ka31b & $2.25^{\mathrm{h}-\mathrm{n}}$ \\
\hline ko13a & $1.63^{e-j}$ & ko7c & $1.63^{\mathrm{e}-\mathrm{i}}$ & ko31c & $2.25^{\mathrm{h}-\mathrm{n}}$ \\
\hline ko14a & $1.63^{e-j}$ & ka16 c & $1.50^{f-j}$ & G20b & $2.13^{\mathrm{i}-\mathrm{o}}$ \\
\hline ko27b & $1.63^{e-j}$ & $\mathrm{ka} 24 \mathrm{a}$ & $1.50^{\mathrm{f}-\mathrm{j}}$ & G22b & $2.13^{\mathrm{i}-\mathrm{o}}$ \\
\hline ko30a & $1.63^{e-j}$ & ka25 a & $1.50^{\mathrm{f}-\mathrm{j}}$ & ka12a & $2.13^{\mathrm{i}-\mathrm{o}}$ \\
\hline $\mathrm{ka} 25 \mathrm{a}$ & $1.50^{f-j}$ & kol3a & $1.50^{f-j}$ & kol3c & $2.13^{\mathrm{i}-\mathrm{o}}$ \\
\hline kol6a & $1.50^{\mathrm{f}-\mathrm{j}}$ & kol5c & $1.50^{\mathrm{f}-\mathrm{j}}$ & G9a & $2.00^{\mathrm{j}-\mathrm{o}}$ \\
\hline ko20a & $1.50^{f-j}$ & $\mathrm{k} 15 \mathrm{~b}$ & $1.38^{g-j}$ & $\mathrm{k} 10 \mathrm{c}$ & $2.00^{\mathrm{j}-\mathrm{o}}$ \\
\hline $\mathrm{k} 15 \mathrm{a}$ & $1.50^{f-j}$ & kalc & $1.38^{\mathrm{g}-\mathrm{j}}$ & ko29b & $2.00^{\mathrm{j}-\mathrm{o}}$ \\
\hline kal4b & $1.50^{f-j}$ & ko27b & $1.38^{g-j}$ & $\mathrm{k} 24 \mathrm{c}$ & $1.88^{\mathrm{k}-\mathrm{p}}$ \\
\hline ka31b & $1.38^{g-j}$ & $\mathrm{k} 24 \mathrm{c}$ & $1.25^{\mathrm{h}-\mathrm{j}}$ & ka9a & $1.88^{\mathrm{k}-\mathrm{p}}$ \\
\hline ko29b & $1.38^{g-j}$ & ka9a & $1.25^{\mathrm{h}-\mathrm{j}}$ & kol5c & $1.75^{1-\mathrm{p}}$ \\
\hline kol2c & $1.25^{\mathrm{h}-\mathrm{j}}$ & ka26 c & $1.13^{\mathrm{ij}}$ & ka26 c & $1.63^{\mathrm{m}-\mathrm{p}}$ \\
\hline ka22b & $1.13^{\mathrm{ij}}$ & ko12c & $1.13^{\mathrm{ij}}$ & ko27b & $1.50^{\mathrm{n}-\mathrm{p}}$ \\
\hline ko20b & $1.13^{\mathrm{ij}}$ & ko29a & $1.13^{\mathrm{ij}}$ & kollb & $1.38^{\mathrm{op}}$ \\
\hline G22b & $1.00^{j}$ & ko24b & $1.00^{\mathrm{j}}$ & G19c & $1.13^{\mathrm{p}}$ \\
\hline LSD & 0.7251 & LSD & 0.6077 & LSD & 0.7833 \\
\hline$P$ value & $<0.001$ & $P$ value & $<0.001$ & $P$ value & $<0.001$ \\
\hline
\end{tabular}

${ }^{*}$ Data represent means of three replications. Means within a column and followed by same letter(s) are not significantly different at $P \geq 0.05$ according to Fisher's protected LSD test. 
TABLE 4: Effect of selected fungicides on C. gloeosporioides sporulation.

\begin{tabular}{|c|c|c|}
\hline Fungicide & Concentration $(\mathrm{g} / \mathrm{l})$ & Mean number of spores $\left(\times 10^{6}\right) / \mathrm{ml}$ from 10 -day-old cultures \\
\hline \multirow{6}{*}{ Milraz } & 0.25 & $1.90^{* \mathrm{~b}}$ \\
\hline & 0.50 & $1.33^{\mathrm{c}}$ \\
\hline & 1.00 & $0.35^{\mathrm{d}}$ \\
\hline & Control & $3.65^{\mathrm{a}}$ \\
\hline & LSD & 0.1792 \\
\hline & $P$ value & $<0.001$ \\
\hline \multirow{6}{*}{ Copper oxychloride } & 0.88 & $1.95^{\mathrm{b}}$ \\
\hline & 1.75 & $1.22^{\mathrm{c}}$ \\
\hline & 3.50 & $0.59^{\mathrm{d}}$ \\
\hline & Control & $3.92^{\mathrm{a}}$ \\
\hline & LSD & 0.2138 \\
\hline & $P$ value & $<0.001$ \\
\hline \multirow{6}{*}{ Bayleton } & 0.125 & $3.01^{\mathrm{b}}$ \\
\hline & 0.25 & $1.72^{\mathrm{c}}$ \\
\hline & 0.5 & $0.92^{\mathrm{d}}$ \\
\hline & Control & $4.69^{\mathrm{a}}$ \\
\hline & LSD & 0.231 \\
\hline & $P$ value & $<0.001$ \\
\hline
\end{tabular}

${ }^{*}$ Data represent means of three replications. Means followed by same letter are not significantly different at $P \geq 0.05$ according to Fisher's protected LSD test.

\section{Acknowledgments}

The authors thank the management and technical team at KALRO, Kandara, where this work was done.

\section{References}

[1] J. E. Erpelding, "Field assessment of anthracnose disease response for the Sorghum germplasm collection from the Mopti region," American journal of Agricultural and Biological Sciences, vol. 5, no. 3, pp. 363-369, 2010.

[2] M. Masyahit, K. Sijam, Y. Awang, and M. G. M. Satar, “The first report of the occurrence of anthracnose disease caused by Colletotrichum gloeosporioides (Penz.) Penz. \& Sacc. on dragon fruit (Hylocereus spp.) in Peninsular Malaysia," American Journal of Applied Sciences, vol. 6, no. 5, pp. 902-912, 2009.

[3] O. A. Amusa and M. O. O. Ashaye, "Guava Fruit Anthracnose and the Effects on its Nutritional and Market Values in Ibadan, Nigeria," World Journal of Agricultural Sciences, vol. 1, no. 2, pp. 169-172, 2005.

[4] A. Gautam, "Colletotrichum gloeosporioides: Biology, pathogenicity and management in India," Journal of Plant Physiology Pathology, vol. 2, no. 2, 2014.

[5] G. N. Agrios, Plant Pathology, Elsevier Academic Press, 2005.

[6] S. L. Willingham, A. W. Cooke, L. M. Coates, and K. G. Pegg, "Pepper spot: A new preharvest Colletotrichum disease of avocado cv. Hass," Australasian Plant Pathology, vol. 29, no. 2, p. $151,2000$.

[7] Y. Siddiqui and A. Ali, Colletotrichum gloeosporioides (Anthracnose). Postharvest Decay: Control Strategies, Elsevier, 2014.

[8] F. Bi, D. Ment, N. Luria, X. Meng, and D. Prusky, "Mutation of AREA affects growth, sporulation, nitrogen regulation, and pathogenicity in Colletotrichum gloeosporioides," Fungal Genetics and Biology, vol. 99, pp. 29-39, 2017.
[9] M. Bill, D. Sivakumar, L. Korsten, and A. K. Thompson, "The efficacy of combined application of edible coatings and thyme oil in inducing resistance components in avocado (Persea americana Mill.) against anthracnose during post-harvest storage," Crop Protection, vol. 64, pp. 159-167, 2014.

[10] M. Bill, D. Sivakumar, A. K. Thompson, and L. Korsten, "Avocado Fruit Quality Management during the Postharvest Supply Chain," Food Reviews International, vol. 30, no. 3, pp. 169-202, 2014.

[11] L. Korsten and C. Bornman, "Biological control in Africa: Can it provide a sustainable solution for control of fruit diseases?" South African Journal of Botany, vol. 70, no. 1, pp. 128-139, 2004.

[12] D. Sivakumar, M. Bill, L. Korsten, and K. Thompson, "Integrated Application of Chitosan Coating with Different Postharvest Treatments in the Control of Postharvest Decay and Maintenance of Overall Fruit Quality," Chitosan in the Preservation of Agricultural Commodities, Elsevier Inc, pp. 127-153, 2016.

[13] H. J. Kim, E. J. Lee, S. H. Park, H.-S. Lee, and N. Chung, "Biological Control of Anthracnose (Colletotrichum gloeosporioides) in Pepper and Cherry Tomato by Streptomyces sp. A1022," Journal of Agricultural Science, vol. 6, no. 2, pp. 54-62, 2014.

[14] J. Janick, Horticultural Reviews, vol. 22, John Wiley and Sons, 1998.

[15] S. Bautista-Baños, D. Sivakumar, A. Bello-Pérez, R. VillanuevaArce, and M. Hernández-López, "A review of the management alternatives for controlling fungi on papaya fruit during the postharvest supply chain," Crop Protection, vol. 49, pp. 8-20, 2013.

[16] A. Karabulut and N. Baykal, "Evaluation of the use of microwave power for the control of postharvest diseases of peaches," Postharvest Biology and Technology, vol. 26, no. 2, pp. 237-240, 2002.

[17] S. Bautista-Baños, M. Hernández-López, E. Bosquez-Molina, and C. L. Wilson, "Effects of chitosan and plant extracts on growth of Colletotrichum gloeosporioides, anthracnose levels 
and quality of papaya fruit," Crop Protection, vol. 22, no. 9, pp. 1087-1092, 2003.

[18] A. Perumal, P. Sellamuthu, R. Nambiar, and E. Sadiku, "Antifungal activity of five different essential oils in vapour phase for the control of Colletotrichum gloeosporioides and Lasiodiplodia theobromae in vitro and on mango," International Journal of Food Science \& Technology, vol. 87, pp. 34-46, 2016.

[19] P. Sellamuthu, D. Sivakumar, P. Soundy, and L. Korsten, "Essential oil vapours suppress the development of anthracnose and enhance defence related and antioxidant enzyme activities in avocado fruit," Postharvest Biology and Technology, vol. 19, no. 2, pp. 45-48, 2013.

[20] L. L. Barrera-Necha, S. Bautista-Baños, H. E. Flores-Moctezuma, and A. R. Estudillo, "Efficacy of essential oils on the conidial germination, growth of colletotrichum gloeosporioides (penz.) penz. and sacc and control of postharvest diseases in papaya (carica papaya 1.)," Plant Pathology, vol. 7, no. 2, pp. 174-178, 2008.

[21] B. T. Mengistie, A. P. J. Mol, and P. Oosterveer, "Pesticide use practices among smallholder vegetable farmers in Ethiopian Central Rift Valley," Environment, Development and Sustainability, vol. 19, no. 1, pp. 301-324, 2015.

[22] L. Smith, E. Dann, J. Leonardi, and J. Dean, "Exploring nontraditional products for management of postharvest anthracnose and stem end rot in avocado," VI the World Avocado, 2011.

[23] A. R, N. D. Das, and D. Krishnaveni, "In vitro antagonism of Trichoderma spp. against two fungal pathogens of Castor," Indian Journal of Plant Protection, vol. 23, no. 2, pp. 152-155, 1995.

[24] G. M. Sanders, L. Korsten, and F. C. Wehner, "Survey of fungicide sensitivity in Colletotrichum gloeosporioides from different avocado and mango production areas in South Africa," European Journal of Plant Pathology, vol. 106, no. 8, pp. 745-752, 2000.

[25] P. Leroux and A.-S. Walker, "Activity of fungicides and modulators of membrane drug transporters in field strains of Botrytis cinerea displaying multidrug resistance," European Journal of Plant Pathology, vol. 135, no. 4, pp. 683-693, 2013. 


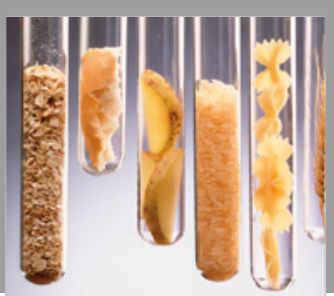

International Journal of Food Science

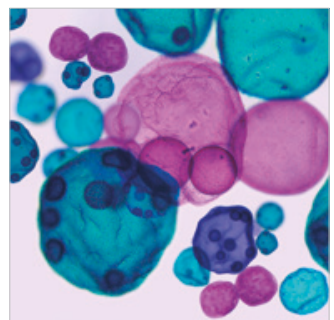

International Journal of Microbiology
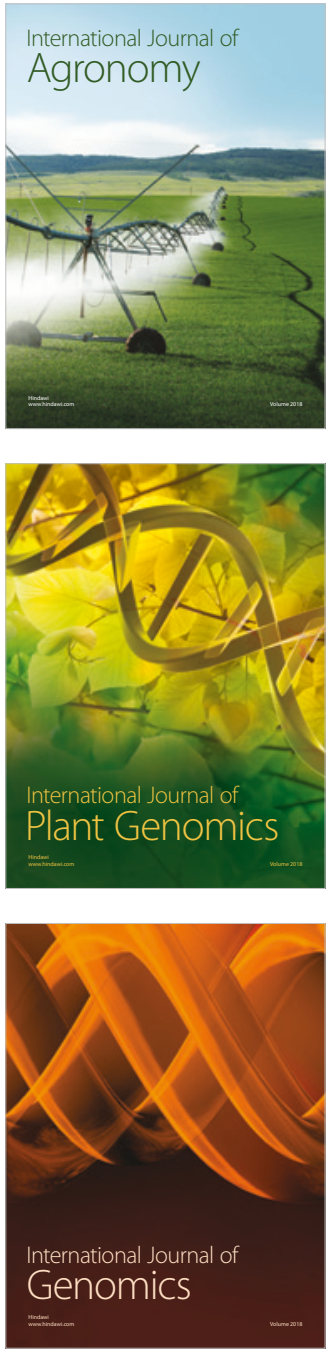

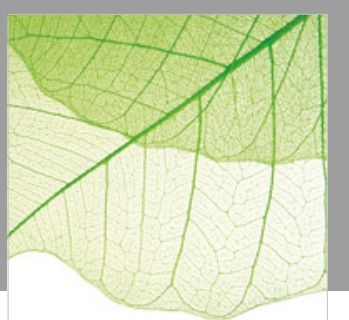

Journal of Botany
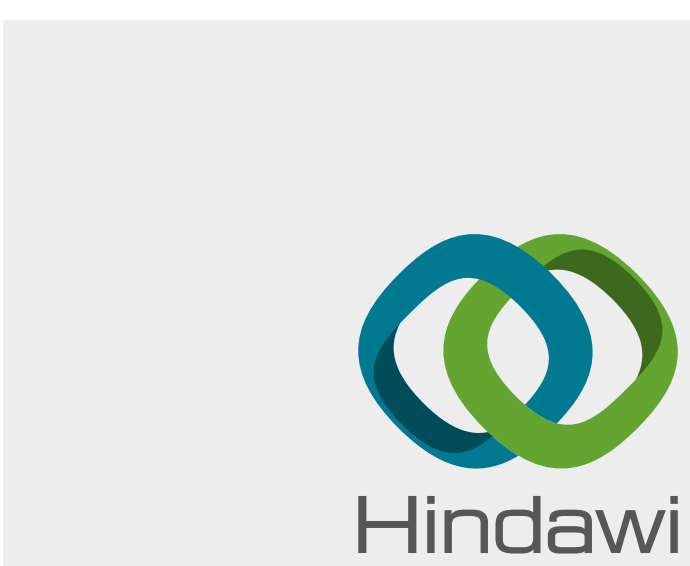

Submit your manuscripts at

www.hindawi.com
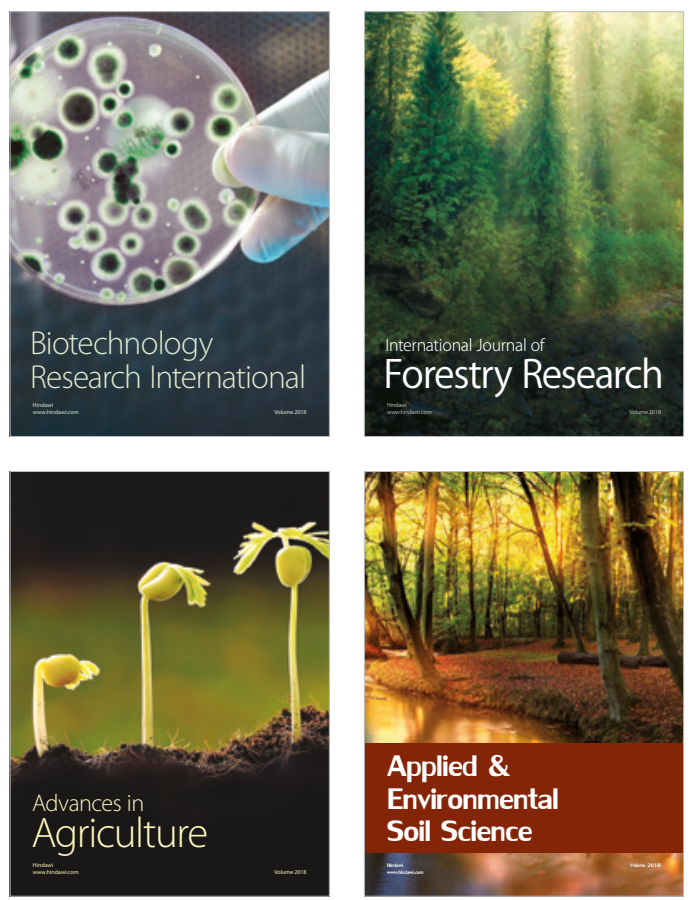

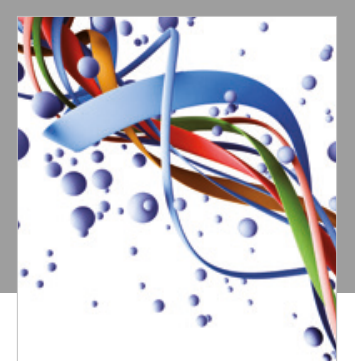

Scientifica

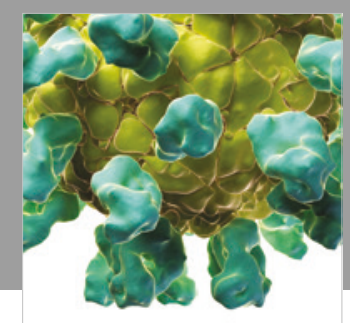

Veterinary Medicine International

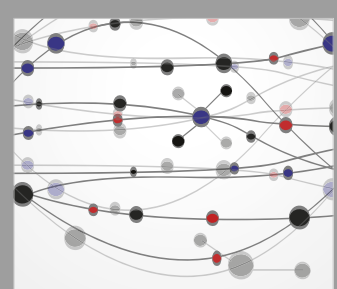

The Scientific World Journal
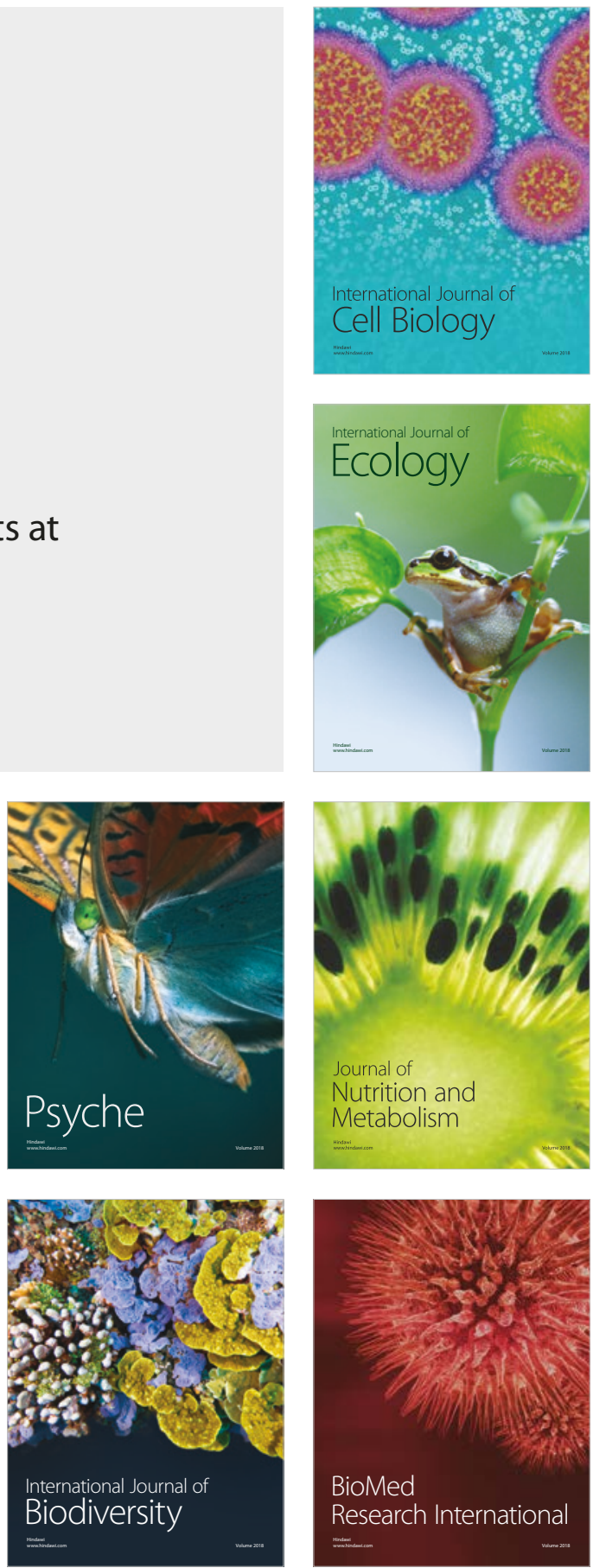